Sanchenia, Z. $\cdot$ T.M. Onggo $\cdot$ W. Sutari

\title{
Respon pertumbuhan dan hasil panen rebung periode pertama lima kultivar asparagus pada berbagai konsentrasi larutan garam
}

\section{Growth response and first period spears yield of five asparagus cultivars toward various salt solution concentrations}

Diterima : 11 Desember 2017/Disetujui : 18 Desember 2017 / Dipublikasikan : 30 Desember 2017

(CDepartment of Crop Science, Padjadjaran University

\begin{abstract}
Asparagus spears (Asparagus officionalis L.) is the high economic value vegetables in the world as well as in Indonesia. The asparagus cultivars planted in Indonesia are generally introduced from sub-tropical area which has different environment condition than Indonesia, thus the growth and production are not optimal. The high temperature and humidity in Indonesia caused high deployment of plant's diseases. The application of salt solution on growing media aims to control root diseases so that asparagus's plants can grow well. The experiment was aimed to study the influence of salt solution and asparagus cultivars on growth and spears yield planted in the medium elevation of Jatinangor. This experiment was conducted under plastic shade in Controlled Culture Laboratory of Agriculture FacultyPadjadjaran University at the altitude of 730 meters above sea level from January until July 2016. The experimental design used was SplitPlot Design with two replications. The main plot was the asparagus cultivars which consisted of five levels; Atlas F1, De Paoli F1, Jing Green F1, San Knight F1 and Jaleo. The sub plot was the salt solution concentration consisted of three levels; $1 \mathrm{~g} / \mathrm{L}, 2 \mathrm{~g} / \mathrm{L}$ dan $3 \mathrm{~g} / \mathrm{L}$. The results showed no interaction effect between the asparagus cultivars and various consentrations of salt on the growth, yield and quality of spears; The growth and quality of spears were not different between five asparagus cultivars, but the percentage of marketable spears number of the Atlas and Jaleo cultivars were higher than
\end{abstract}

\footnotetext{
Dikomunikasikan oleh Syariful Mubarok

Sanchenia, Z. ${ }^{1} \cdot$ T.M. Onggo ${ }^{2} \cdot$ W. Sutari ${ }^{2}$

${ }^{1}$ Alumni Program Studi Agronomi Fakultas Pertanian

Universitas Padjadjaran

2Staf Pengajar Program Studi Agronomi Fakultas Pertanian

Universitas Padjadjaran

Korespondensi : tinong2002@yahoo.com
}

De Paoli cultivars; the salt solution concentrations was not different toward growth, yield and quality of spears.

Keywords: plant's height, steam number, shoot weight, spear number, spear weight.

Sari Rebung asparagus (Asparagus officionalis L.) termasuk salah satu sayuran yang bernilai ekonomi tinggi di dunia juga di Indonesia. Kultivar asparagus yang ditanam di Indonesia umumnya merupakan kultivar introduksi dari daerah subtropis, sehingga pertumbuhan dan produksinya di Indonesia kurang optimal. Indonesia memiliki suhu dan kelembaban yang cukup tinggi sehingga dapat menyebabkan serangan berbagai penyakit pada tanaman asparagus. Aplikasi larutan garam pada media tanam mampu mengendalikan penyakit akar sehingga asparagus akan tumbuh dengan baik. Percobaan bertujuan mengetahui pengaruh konsentrasi larutan garam dan kultivar asparagus yang cocok untuk dataran medium Jatinangor supaya diperoleh pertumbuhan dan hasil rebung asparagus yang baik. Percobaan dilaksanakan di Laboratorium Kultur Terkendali Fakultas Pertanian Universitas Padjadjaran Jatinangor Kabupaten Sumedang pada ketinggian tempat sekitar $730 \mathrm{mdpl}$, sejak bulan Januari sampai Juli 2016. Penanaman dilakukan di bawah naungan plastik transparan. Rancangan percobaan menggunakan Rancangan Petak Terbagi (RPT) atau Split-Plot Design dengan dua ulangan. Petak utama adalah kultivar asparagus yang terdiri dari lima taraf yaitu kultivar Atlas F1, De Paoli F1, Jing Green F1, San Knight F1 dan Jaleo. Anak petak adalah konsentrasi larutan garam yang terdiri dari tiga taraf yaitu 1 $\mathrm{g} / \mathrm{L}, 2 \mathrm{~g} / \mathrm{L}$ dan $3 \mathrm{~g} / \mathrm{L}$. Hasil percobaan menunjukkan tidak terdapat hubungan yang saling mempengaruhi antara lima kultivar 
asparagus dan konsentrasi larutan garam terhadap pertumbuhan, hasil dan kualitas rebung. Pertumbuhan dan kualitas rebung asparagus dari lima kultivar yang di uji tidak berbeda nyata. Kultivar Atlas dan Jaleo mampu menghasilkan persentase jumlah dan bobot rebung layak pasar lebih tinggi dibandingkan kultivar De Paoli. Perbedaan konsentrasi larutan garam tidak berpengaruh terhadap pertumbuhan, hasil panen dan kualitas rebung.

Kata kunci: tinggi tanaman, jumlah batang, bobot brangkasan, bobot rebung, jumlah rebung.

\section{Pendahuluan}

Rebung asparagus (Asparagus officionalis L.) termasuk salah satu sayuran yang bernilai ekonomi tinggi di dunia juga di Indonesia. Rebung asparagus memiliki kandungan nutrisi yang tinggi terutama mengandung protein asparagin yang berguna untuk kesehatan. Menurut Sudjatmiko (1994), tanaman asparagus berpotensi dibudidayakan di Indonesia pada suhu $25^{\circ} \mathrm{C}-35^{\circ} \mathrm{C}$ (suhu tropis), namun kondisi suhu seperti ini memiliki tingkat kelembaban udara yang tinggi dapat menyebabkan penyebaran penyakit pada tanaman asparagus.

Kultivar asparagus yang ditanam di Indonesia umumnya merupakan introduksi dari daerah subtropis yang memiliki kondisi lingkungan yang berbeda dengan Indonesia, sehingga pertumbuhan dan produksinya kurang optimal. Menurut Onggo (2008), kultivar Atlas F1 sudah banyak ditanam di Indonesia dan berkembang baik khususnya di Jawa Barat. Kultivar ini memiliki ketahananan terhadap penyakit dan menghasilkan produksi rebung yang lebih tinggi dengan jumlah rebung berkualitas A lebih banyak dibandingkan delapan kultivar asparagus lainnya yang berasal dari Amerika dan New Zealand. Pemilihan kultivar baru diharapkan mampu memberikan perbaikan dalam hasil produksi asparagus dan mengatasi masalah penyakit yang sering dialami pada tanaman asparagus di daerah tropis.

Pertumbuhan yang baik pada tanaman asparagus ditandai dengan hasil rebung yang tinggi, memiliki diameter rebung layak pasar lebih dari $0,8 \mathrm{~cm}$, juga tahan terhadap serangan penyakit. Penyakit yang biasanya menyerang asparagus di daerah tropis adalah penyakit karat (Puccinia asparagi), bercak batang (stem blight) dan layu fusarium (Fusarium sp.) (Ashari, 1995). Masalah penyakit seperti ini harus ditangani antara lain dengan penggunaan kultivar yang tahan terhadap penyakit dan mampu beradaptasi dengan baik pada iklim tropis yang panas dan lembap.

Serangan penyakit pada tanaman asparagus merupakan salah satu kendala dalam budidaya asparagus yang dapat mengganggu pertumbuhan dan menurunkan produksi asparagus, sehingga diperlukan tindakan penanganan dalam mencegah permasalahan penyakit yang menyerang tanaman ini. Pemberian larutan garam $(\mathrm{NaCl})$ pada media tanam merupakan salah satu cara dalam mengatasi permasalahan penyakit layu fusarium. Aplikasi larutan garam pada media tanam asparagus dapat digunakan bila tanaman yang ditanam tahan terhadap kadar garam yang tinggi. Berdasarkan penelitian yang dilakukan oleh Poll dan Bleeker (1998), penggunaan $\mathrm{NaCl}$ sebanyak 2 ton/ha pada tanaman asparagus dapat mengurangi serangan penyakit Fusarium sp. dan menekan spesies gulma yang tumbuh hingga $100 \%$ di lahan asparagus.

Penelitian Kruistum et al., (2005) juga menunjukkan tanaman asparagus mengalami peningkatan hasil panen di tahun kedua dengan pemberian $\mathrm{NaCl} 1$ ton/ha. Pemberian larutan garam juga berpengaruh dalam pemulihan produksi akibat penyakit karat yang disebabkan Fusarium sp.. Menurut Gonzalez (2008), pemberian larutan garam 1,8 ton/ha pada asparagus, tidak berakibat buruk bagi pertumbuhan dan perkembangan tanaman selama tujuh tahun. Sedangkan pada penelitian sebelumnya mengenai pengaruh konsentrasi larutan garam terhadap pertumbuhan dan kualitas bibit lima kultivar asparagus yang telah dilakukan di dataran tinggi Lembang Jawa Barat, aplikasi konsentrasi larutan garam 4 dan $7 \mathrm{~g} / \mathrm{L}$ pada bibit asparagus menunjukkan tinggi bibit, jumlah batang, bobot segar bibit, bobot shoot, bobot crown dan volume crown lebih rendah dibandingkan konsentrasi larutan garam $1 \mathrm{~g} / \mathrm{L}$ (Kusumiyati et al., 2017). Dari data tersebut diperlukan penelitian lanjutan untuk mengetahui konsentrasi larutan garam berapa yang dapat diaplikasikan pada tanaman asparagus di dataran medium dalam usaha mengatasi serangan penyakit yang diharapkan menjadi solusi dan mendapatkan kultivar yang mempunyai respon pertumbuhan vegetatif yang baik sehingga produksinya tinggi. 


\section{Bahan dan Metode}

Percobaan dilakukan di Laboratorium Kultur Terkendali Fakultas Pertanian Universitas Padjadjaran Jatinangor Kabupaten Sumedang Jawa Barat pada ketinggian tempat sekitar 730 meter di atas permukaan laut (dpl) sehingga tergolong dataran medium. Asparagus ditanam dengan naungan plastik transparan untuk menghindari pengaruh air hujan. Percobaan dilaksanakan selama 6 bulan, dari bulan Januari sampai bulan Juli 2016.

Metode percobaan yang digunakan adalah percobaan lapangan dengan Rancangan Petak Terbagi (RPT) atau Split-Plot Design, dengan jumlah ulangan dua. Petak utama (main plot) adalah penggunaan kultivar asparagus (K) yang terdiri dari lima taraf, yaitu $\mathrm{k}_{1}$ Atlas F1 (dari California Asparagus Seed and Transplant USA); $\mathrm{k}_{2}$ De Paoli F1 Hybrid (dari UC Riverside), $\mathrm{k}_{3}$ Jing Green No.1 Hybrid F1 (dari Beijing Academic of Agriculture and Forestry Sci. China); $\mathrm{k}_{4}$ San Knight Hybrid F1 (dari Atlas Seeds, BJ. Co. Ltd); dan $\mathrm{k}_{5}$ Jaleo (dari Vilmorin, Perancis). Anak petak (sub plot) yaitu konsentrasi larutan garam (G) yang terdiri dari tiga taraf, yaitu $g_{1}(1,0 \mathrm{~g} / \mathrm{L}), \mathrm{g}_{2}(2,0$ $\mathrm{g} / \mathrm{L})$ dan $\mathrm{g}_{3}(3,0 \mathrm{~g} / \mathrm{L})$. Ukuran petak panjang $5,0 \mathrm{~m}$ dan lebar 1,0m. Dalam 1 plot percobaan terdiri dari 20 tanaman dan diambil 4 sampel tanaman secara acak sebagai bahan pengamatan pertumbuhan. Kegiatan pengamatan pertumbuhan dilakukan dengan interval waktu 2 minggu.

Bahan yang digunakan dalam percobaan ini adalah bibit yang berumur 16 minggu dari lima kultivar asparagus. Bahan lainnya yaitu pupuk kandang domba yang telah dikomposkan, pupuk NPK Mutiara 25:7:7 dan 16:16:16 serta garam $(\mathrm{NaCl})$ jenis krosok (garam ikan).

Pengamatan pertumbuhan meliputi tinggi tanaman, jumlah batang dan bobot brangkasan. Pengamatan hasil dan kualitas panen rebung meliputi jumlah dan bobot rebung total per plot, persentase jumlah dan bobot rebung layak pasar dan tidak layak pasar, dan persentase kelas kualitas (grade) rebung. Data hasil diperoleh dari panen rebung selama satu periode panen (12 minggu). Pengaruh perlakuan diuji dengan uji $\mathrm{F}$ dengan taraf nyata 5\%, sedangkan untuk menguji perbedaan nilai rata-rata perlakuan dilakukan dengan uji Duncan pada taraf nyata $5 \%$.

\section{Hasil dan Pembahasan}

Berdasarkan hasil analisis statistik menunjukkan bahwa tidak terdapat interaksi antara jenis kultivar yang digunakan dengan berbagai konsentrasi larutan garam pada semua komponen pertumbuhan.

Tinggi Tanaman Asparagus. Tinggi tanaman dari lima kultivar asparagus pada pengamatan umur 2 MSP hingga 12 MSP tidak menunjukkan perbedaan yang nyata (Tabel 1). Hal ini diduga karena seluruh kultivar asparagus tersebut dapat toleran untuk tumbuh di daerah tropis dengan baik (sesuai deskripsi karakter), sehingga tinggi tanaman ke lima kultivar tersebut tidak menunjukkan perbedaan yang nyata. Tinggi tanaman lima kultivar asparagus sejak umur 2 MSP hingga 12 MSP meningkat setiap minggunya yang berarti sampai umur 12 minggu tanaman masih dalam stadia pertumbuhan.

Demikian pula halnya dengan aplikasi beberapa konsentrasi larutan garam, masingmasing tidak memberikan penganruh yang berbeda nyata terhadap tinggi tanaman asparagus pada umur 2-12 MSP. Hal ini menunjukkan bahwa konstrasi garam $1 \mathrm{~g} / \mathrm{L}$ hingga $3 \mathrm{~g} / \mathrm{L}$ masih dapat ditoleransi oleh tanaman asparagus, tidak menyebabkan pertumbuhan tanaman asparagus terganggu.

Tanaman yang toleran terhadap konsen-trasi larutan garam dan dapat tumbuh dengan baik diduga karena dapat adanyan kemampuan untuk mempertahankan keseimbangan antara tekanan osmotik dalam sel dengan larutan garam yang ada di luar sel. Tanaman yang toleran terhadap larutan garam ditunjukkan dengan tidak terganggunya pertumbuhan tanaman apabila terjadi peningkatan konsentrasi larutan garam (Beltagi et al., 2006). Menurut Grattan \& Grieve (1999), dampak yang disebabkan oleh aktivitas pertukaran ion $\mathrm{Na}, \mathrm{Mg}$ dan $\mathrm{Cl}$ saat pemberian larutan garam dapat menyebabkan ketidakseimbangan unsur hara dalam tanah serta menurunkan pertumbuhan dan kualitas tanaman.

Mazher et al. (2007) juga menyatakan pemberian larutan garam yang masih dapat ditoleransi oleh tanaman tidak akan mengubah aktivitas fotosintesis sehingga tidak menyebabkan penurunan karbohidrat, tidak mengganggu pembentukan hormon, aktivitas enzim maupun sintesis protein yang dapat menghambat pertumbuhan tanaman. Dengan 
demikian dapat dikatakan bahwa sampai konsentrasi $3 \mathrm{~g} / \mathrm{L}$ larutan garam yang diaplikasikan masih dapat di toleransi dan tidak mengganggu pertumbuhan tanaman asparagus.

Jumlah Batang Tanaman Asparagus. Berdasarkan data pada Tabel 2 tersebut tampak bahwa dan jumlah batang dari lima kultivar asparagus terus mengalami pertambahan sejak umur 2 MSP hingga 12 MSP. Berdasarkan hasil uji statistik menunjukkan bahwa jumlah batang dari lima kultivar asparagus tidak memperlihatkan perbedaan yang nyata pada umur 2 MSP hingga 12 MSP (Tabel 2).

Kultivar Jaleo menunjukkan kecenderungan memiliki jumlah batang yang lebih banyak dibandingkan kultivar lainnya sejak umur 2 MSP hingga 12 MSP. Hal ini menunjukkan bahwa pertumbuhan kultivar Jaleo lebih cepat dan dapat beradaptasi pada daerah tropis lebih baik dibandingkan empat kultivar lainnya. Pernyataan tersebut sesuai dengan hasil penelitian Cantaluppi (2012) yang menyatakan bahwa kultivar Jaleo memiliki pertumbuhan yang sangat cepat dan mudah beradaptasi dengan lingkungan tumbuhnya.

Data tersebut juga menunjukkan pengaruh beberapa konsentrasi larutan garam tidak berbeda nyata terhadap jumlah batang pada umur 2 MSP hingga 12 MSP. Batang pada tanaman asparagus sebenarnya adalah daun dari tanaman yang termodifikasi (cladophyll) (Drost, 1997). Jumlah batang yang banyak pada asparagus menunjukkan jumlah daun yang banyak pula. Salah satu ciri tingginya produktivitas tanaman adalah kemampuan tanaman untuk memproduksi daun lebih banyak, sebab daun merupakan tempat terjadinya proses fotosintesis.

Tabel 1. Tinggi Tanaman Lima Kultivar Asparagus pada Berbagai Konsentrasi Larutan Garam Umur 2, 4, 6, 8, 10 dan 12 MSP.

\begin{tabular}{|c|c|c|c|c|c|c|}
\hline \multirow{2}{*}{ Perlakuan } & \multicolumn{6}{|c|}{ Tinggi Tanaman $(\mathrm{cm})$} \\
\hline & $2 \mathrm{MSP}$ & $4 \mathrm{MSP}$ & 6 MSP & 8 MSP & $10 \mathrm{MSP}$ & $12 \mathrm{MSP}$ \\
\hline \multicolumn{7}{|l|}{ Kultivar (K) } \\
\hline $\mathrm{k}_{1}=$ Atlas F1 & 121,0 & 123,8 & 136,8 & 146,2 & 154,6 & 176,9 \\
\hline $\mathrm{k}_{2}=$ De Paoli F1 & 111,7 & 120,1 & 133,1 & 143,9 & 150,2 & 171,1 \\
\hline $\mathrm{k}_{3}=$ Jing Green F1 & 110,4 & 111,5 & 120,4 & 128,5 & 135,2 & 165,3 \\
\hline $\mathrm{k}_{4}=$ San Knight & 110,6 & 113,6 & 123,6 & 136,3 & 144,3 & 163,7 \\
\hline $\mathrm{k}_{5}=$ Jaleo & 109,7 & 113,0 & 124,6 & 130,1 & 138,8 & 171,0 \\
\hline \multicolumn{7}{|c|}{ Kons. Larutan Garam(G) } \\
\hline $\mathrm{g}_{1}=1 \mathrm{~g} / \mathrm{L}$ & 111,4 & 116,9 & 128,8 & 138,1 & 145,8 & 170,0 \\
\hline $\mathrm{g}_{2}=2 \mathrm{~g} / \mathrm{L}$ & 113,5 & 116,4 & 127,2 & 135,5 & 143,3 & 171,2 \\
\hline $\mathrm{g}_{3}=3 \mathrm{~g} / \mathrm{L}$ & 113,2 & 115,8 & 127,2 & 137,5 & 144,8 & 167,6 \\
\hline
\end{tabular}

Keterangan: Hasil uji F menunjukkan tinggi tanaman pada semua MSP tidak berbeda nyata, sehingga tidak dilakukan uji lanjut. MSP = Minggu Setelah Perlakuan.

Tabel 2. Jumlah Batang Lima Kultivar Asparagus pada Berbagai Konsentrasi Larutan Garam Umur 2, 4, 6, 8, 10 dan 12 MSP

\begin{tabular}{lcccccc}
\hline \multicolumn{1}{c}{ Perlakuan } & \multicolumn{5}{c}{ Jumlah Batang } \\
\cline { 2 - 7 } & 2 MSP & 4 MSP & 6 MSP & 8 MSP & 10 MSP & 12 MSP \\
\hline Kultivar (K) & 10,6 & 12,2 & 14,6 & 16,3 & 17,6 & 19,1 \\
k1 = Atlas & 9,8 & 11,4 & 13,3 & 14,7 & 16,7 & 19,1 \\
k2 = De Paoli & 9,0 & 10,7 & 12,1 & 13,0 & 13,7 & 15,2 \\
k3 = Jing Green & 9,1 & 11,3 & 12,4 & 13,0 & 15,0 & 17,6 \\
k4 = San Knight & 14,0 & 16,4 & 17,4 & 18,1 & 20,0 & 21,2 \\
k5 = Jaleo & & & & & \\
Kon. Lar. Garam (G) & 9,6 & 11,7 & 13,2 & 14,3 & 15,1 & 17,5 \\
g1 = 1 g/L & 11,2 & 12,9 & 14,6 & 15,5 & 18,0 & 19,2 \\
g2 = 2 g/L & 10,6 & 12,6 & 14,1 & 15,2 & 16,8 & 18,6 \\
g3 = 3 g/L &
\end{tabular}

Keterangan: Hasil uji F menunjukkan jumlah batang pada semua MSP tidak berbeda nyata, sehingga tidak dilakukan uji lanjut. MSP = Minggu Setelah Perlakuan. 
Munns (2002) menyatakan bahwa sel pada tanaman tidak akan mengalami kematian yang cepat apabila konsentrasi larutan garam yang diberikan ke tanaman masih dalam batas wajar dan masih dapat ditampung oleh vakuola, sehingga tidak akan terjadi penurunan jumlah daun tua karena penimbunan larutan garam dalam dinding sel dan sitoplasma. Hasil penelitian Mathur et al. (2006) juga menjelaskan bahwa peningkatan konsentrasi larutan garam yang masih dalam batas toleran terhadap tanaman tidak akan menyebabkan penurunan sel di daerah daun.

Bobot Brangkasan Tanaman Asparagus. Hasil analisis statistik menunjukkan bobot brangkasan lima kultivar asparagus pada tidak berbeda nyata (Tabel 3). Komponen yang menentukan bobot brangkasan tanaman asparagus adalah tinggi tanaman dan jumlah batang, dan tiap kultivar juga mempunyai ukuran batang yang berbeda. Diduga bahwa ukuran batang kultivar Jing Green dan San Knight lebih kecil dibanding kultivar lain sehingga bobot brangkasannya lebih rendah.

Tabel 3. Bobot Brangkasan Total Per Plot Pada Lima Kultivar Asparagus dan Berbagai Konsentrasi Larutan Garam.

\begin{tabular}{lc}
\hline \multicolumn{1}{c}{ Perlakuan } & $\begin{array}{c}\text { Bobot } \\
\text { Brangkasan } \\
\text { Total / Plot (kg) }\end{array}$ \\
\hline Kultivar (K) & 7,0 \\
$\mathrm{k}_{1}=$ Atlas F1 & 5,7 \\
$\mathrm{k}_{2}=$ De Paoli F1 & 4,9 \\
$\mathrm{k}_{3}=$ Jing Green F1 & 5,0 \\
$\mathrm{k}_{4}=$ San Knight F1 & 11,5 \\
$\mathrm{k}_{5}=$ Jaleo & 6,9 \\
Konsentrasi Larutan Garam (G) & 6,9 \\
$\mathrm{~g}_{1}=1 \mathrm{~g} / \mathrm{L}$ & 6,6 \\
$\mathrm{~g}_{2}=2 \mathrm{~g} / \mathrm{L}$ & \\
$\mathrm{g}_{3}=3$ g/L & \multicolumn{2}{c}{ Keterangan: Hasil uji $\mathrm{F}$ menunjukkan bobot } \\
brangkasan total per plot tidak berbeda nyata, \\
sehingga tidak dilakukan uji lanjut.
\end{tabular}

Dari data analisis statistik bobot brang-kasan lima kultivar asparagus di dapat nilai koefisien variansi $(\mathrm{CV})$ 21,16\% yang berarti keseragaman tanaman rendah dan menyebabkan galat percobaan relatif lebih besar. Gasperz (2006) menyatakan bahwa nilai koefisien variansi yang lebih besar dari 20\% berarti galat percobaan tersebut relatif besar sehingga perbedaan yang cukup besar tidak memberikan nilai signifikansi. Ini yang menyebabkan nilai rata-rata data yang besar antara kultivar Jaleo dan Jing Green serta San Knight masih menunjukkan tidak berbeda nyata pada uji lanjut yang dilakukan.

Data pada Tabel 3 juga memperlihatkan hasil analisis bobot brangkasan pada tiga konsentrasi larutan garam tidak berbeda nyata. Seperti yang telah dijelaskan di depan bahwa respon lima kultivar terhadap konsentrasi larutan garam adalah sama. Ketiga konsentrasi larutan garam tersebut masih dapat ditoleransi oleh tanaman sehingga bobot brangkasannya tidak berbeda.

Jumlah dan Bobot Rebung Total Per Plot Panen Periode Pertama. Data pada Tabel 4 menunjukkan bahwa seluruh kultivar asparagus yang diberi berbagai konsentrasi larutan garam memperlihatkan jumlah dan bobot rebung total per plot yang tidak berbeda nyata. Jumlah dan bobot rebung total per plot ini dipengaruhi oleh bobot brangkasan sebelum panen yang juga menunjukkan hasil yang tidak berbeda nyata. Semakin banyak daun yang dihasilkan oleh suatu tanaman, maka semakin baik pula kemampuan tanaman dalam fotosintesisnya. Hasil fotosintesis akan mempengaruhi cadangan makanan tanaman asparagus yang akan tumbuh menjadi rebung. Apabila cadangan makanan yang tersedia sedikit maka rebung yang tumbuh juga sedikit begitupun sebaliknya, sehingga banyaknya bobot brangkasan yang dihasilkan akan menentukan banyaknya rebung yang akan dapat dipanen (Rubatzky dan Yamaguchi, 1999).

Secara statistik jumlah dan bobot rebung total per plot menunjukkan tidak adanya perbedaan, akan tetapi dapat dilihat pada Tabel 4 bahwa kultivar Jaleo memperlihatkan jumlah rebung total per plot yang lebih banyak dibandingkan kultivar Jing Green yang memperoleh jumlah rebung total per plot paling sedikit, sedangkan bobot rebung total per plot kultivar Jaleo tiga kali lebih banyak dari kultivar De Paoli. Hasil tersebut juga membuktikan bahwa bobot brangkasan yang tinggi pada kultivar Jaleo menghasilkan bobot rebung terbanyak.

Perbedaan hasil pada jumlah dan bobot rebung total per plot disebabkan oleh kondisi brangkasan masing-masing kultivar, ini berarti brangkasan dari masing-masing kultivar menjadi komponen yang dapat digunakan untuk mendeteksi hasil panen, yaitu apabila hasil brangkasannya banyak maka hasil panen rebungnya juga akan banyak. Perlakuan larutan garam pada ketiga konsentrasi juga menunjukkan hasil yang tidak berbeda. 
Tabel 4 Jumlah Dan Bobot Rebung (G) Total Per Plot Panen Periode Pertama Lima Kultivar Asparagus pada Berbagai Konsentrasi Larutan Garam.

\begin{tabular}{lcc}
\hline \multirow{2}{*}{ Perlakuan } & \multicolumn{2}{c}{ Panen Rebung Total / Plot } \\
\cline { 2 - 3 } & Jumlah & Bobot $(\mathrm{g})$ \\
\hline Kultivar (K) & & \\
$\mathrm{k}_{1}=$ Atlas F1 & 82,3 & 909,2 \\
$\mathrm{k}_{2}=$ De Paoli F1 & 95,3 & 546,3 \\
$\mathrm{k}_{3}=$ Jing Green F1 & 70,0 & 618,8 \\
$\mathrm{k}_{4}=$ San Knight F1 & 94,2 & 769,8 \\
$\mathrm{k}_{5}=$ Jaleo & 126,7 & 1517,7 \\
\hline Konsentrasi Larutan & & \\
Garam (G) & 93,7 & 786,6 \\
$\mathrm{~g}_{1}=1 \mathrm{~g} / \mathrm{L}$ & 90,5 & 854,4 \\
$\mathrm{~g}_{2}=2 \mathrm{~g} / \mathrm{L}$ & 96,9 & 976,1 \\
$\mathrm{~g}_{3}=3 \mathrm{~g} / \mathrm{L}$ & &
\end{tabular}

Keterangan: Data yang dianalisis adalah data hasil transformasi. Hasil uji $\mathrm{F}$ menunjukkan panen rebung total per plot tidak berbeda nyata, sehingga tidak dilakukan uji lanjut.

Persentase Jumlah dan Bobot Rebung Layak Pasar dan Tidak Layak Pasar. Data pada Tabel 5 menunjukkan bahwa persentase jumlah rebung layak pasar kultivar Atlas, San Knight dan Jaleo lebih banyak dibanding kultivar De Paoli, berarti persentase jumlah rebung tidak layak pasar kultivar De Paoli lebih banyak dari kultivar Atlas, San Knight dan Jaleo. Sedangkan pada persentase bobot rebung layak pasar kultivar Atlas, Jing Green dan Jaleo lebih besar dari kultivar De Paoli. Bobot rebung tidak layak pasar kultivar De Paoli juga lebih besar dibanding empat kultivar lainnya.

Hasil di atas dapat disebabkan karena rebung kultivar De Paoli berukuran kecil, selain itu juga banyak rebung yang belum mencapai 30 $\mathrm{cm}$ tetapi tip atau pucuk telah mekar dan rebung tumbuh bengkok atau abnormal. Dari kondisi tersebut dapat diperkirakan bahwa kultivar De Paoli kurang baik beradaptasi di dataran menengah seperti di Jatinangor.

Jumlah dan bobot rebung layak pasar (LP) dan tidak layak pasar (TLP) pada konsentrasi larutan garam juga menunjukkan hasil yang tidak berbeda. Ini menunjukkan genetik tanaman asparagus dapat tahan terhadap konsentrasi larutan garam hingga $3 \mathrm{~g} / \mathrm{L}$, sehingga respon tanaman asparagus dalam menghasilkan rebung juga sama.

Persentase Jumlah dan Bobot Rebung Berdasarkan Kelas Kualitas (Grade). Berdasarkan hasil uji setatistik diketahui persentase jumlah dan bobot rebung berdasarkan kelas kualitas A, B dan C dari lima kultivar asparagus tidak berbeda nyata (Tabel 6). Kultivar De Paoli menghasilkan persentase jumlah rebung grade A lebih banyak dibanding kultivar lain dan kultivar Atlas menghasilkan persentase bobot rebung grade A yang lebih besar. Persentase jumlah dan bobot rebung grade A pada penelitian ini sedikit dan persentase jumlah dan bobot rebung grade $\mathrm{C}$ nya besar.

Penanaman asparagus pada percobaan ini tidak menggunakan mother stalk (batang induk), sehingga pertumbuhan rebung bergantung pada ketersediaan cadangan makanan yang ada di akar dan rhizome. Jika ketersediaan cadangan makanannya sedikit, maka jumlah rebung yang muncul pun sedikit, dan bila jumlah cadangan makanannya banyak, maka rebung yang muncul juga banyak. Semakin banyak jumlah batang

Tabel 5. Persentase Jumlah dan Bobot Rebung Layak Pasar dan Tidak Layak Pasar Lima Kultivar Asparagus dan pada Berbagai Konsentrasi Larutan Garam.

\begin{tabular}{lllll}
\hline \multirow{2}{*}{ Perlakuan } & \multicolumn{2}{c}{ Jumlah Rebung (\%) } & \multicolumn{2}{c}{ Bobot Rebung (\%) } \\
\cline { 2 - 5 } Kultivar (k) & \multicolumn{2}{c}{ LP } & TLP & LPP \\
k1 = Atlas F1 & $49,0 \mathrm{~b}$ & $50,9 \mathrm{a}$ & $72,4 \mathrm{c}$ & $27,6 \mathrm{a}$ \\
k2 = De Paoli F1 & $22,9 \mathrm{a}$ & $77,1 \mathrm{~b}$ & $37,1 \mathrm{a}$ & $62,8 \mathrm{c}$ \\
k3 = Jing Green F1 & $37,6 \mathrm{ab}$ & $62,4 \mathrm{ab}$ & $59,3 \mathrm{bc}$ & $40,7 \mathrm{ab}$ \\
k4 = San Knight F1 & $42,4 \mathrm{~b}$ & $57,6 \mathrm{a}$ & $52,5 \mathrm{~b}$ & $47,5 \mathrm{~b}$ \\
k5 = Jaleo & $41,7 \mathrm{~b}$ & $58,3 \mathrm{a}$ & $66,4 \mathrm{bc}$ & $33,6 \mathrm{a}$ \\
\hline Konsentrasi Larutan Garam (g) & & & & \\
g1 = 1 g/L & 37,2 & 62,8 & 52,9 & 47,1 \\
g2 = 2 g/L & 38,9 & 61,1 & 58,5 & 41,4 \\
g3 = 3 g/L & 40,1 & 59,8 & 61,2 & 38,8 \\
\hline Ketangan
\end{tabular}

Keterangan: Data yang dianalisis adalah data hasil transformasi. TLP $=$ Tidak Layak Pasar, LP = Layak Pasar. Angka rata-rata pada setiap kolom yang diikuti huruf yang sama menunjukkan tidak berbeda nyata menurut Uji Duncan taraf $5 \%$. 
Tabel 6. Persentase Jumlah dan Bobot Rebung Kelas Kualitas Lima Kultivar Asparagus dan pada Berbagai Konsentrasi Larutan Garam.

\begin{tabular}{lccrrrr}
\hline \multirow{2}{*}{ Perlakuan } & \multicolumn{3}{c}{ Jumlah Rebung (\%) } & \multicolumn{3}{c}{ Bobot Rebung (\%) } \\
\cline { 2 - 7 } & A & B & C & A & B & C \\
\hline Kultivar (k) & & & & & & \\
k1 = Atlas F1 & 4,0 & 29,0 & 67,0 & 6,1 & 33,5 & 60,4 \\
k2 = De Paoli F1 & 6,5 & 15,3 & 78,1 & 3,3 & 9,8 & 86,9 \\
k3 = Jing Green F1 & 2,7 & 16,1 & 81,3 & 5,6 & 23,5 & 70,9 \\
k4 = San Knight F1 & 0,3 & 21,3 & 78,4 & 1,2 & 13,9 & 84,9 \\
k5 = Jaleo & 3,9 & 27,5 & 68,5 & 6,0 & 36,1 & 57,9 \\
\hline Kon. Larutan Garam (g) & & & & & & \\
g1 = 1 g/L & 4,1 & 21,1 & 74,8 & 2,7 & 20,1 & 77,2 \\
g2 = 2 g/L & 3,6 & 21,4 & 75,0 & 6,6 & 23,3 & 70,1 \\
g3 = 3 g/L & 2,7 & 23,0 & 74,3 & 4,0 & 26,7 & 69,3 \\
\hline
\end{tabular}

Keterangan: Data yang dianalisis adalah data hasil transformasi; Hasil uji F menunjukkan persentase jumlah dan bobot rebung berdasarkan kelas kualitas tidak berbeda nyata, sehingga tidak dilakukan uji lanjut.

asparagus yang tumbuh, maka semakin kecil ukuran diameter rebung dan semakin sedikit jumlah batang asparagus yang tumbuh maka semakin besar ukuran diameter rebung (Rubatzky dan Yamaguchi, 1999).

Pertumbuhan tanpa mother stalk ini akan menyebabkan pertumbuhan awal rebung besar, akan tetapi selanjutnya makin kecil. Semakin panjang umur panen maka persentase rebung grade A juga akan semakin kecil.

Berdasarkan Tabel 6 juga menunjukkan bahwa persentase jumlah dan bobot rebung berdasarkan kelas kualitas A, B dan C pada ketiga konsentrasi larutan garam tidak berbeda, yang berarti ketiga konsentrasi larutan garam tidak berpengaruh pada pertumbuhan rebung tanaman asparagus. Kualitas rebung yang baik sangat dipengaruhi oleh faktor lingkungan dan faktor genetik.

Berdasarkan hasil dari penelitian ini, kemampuan masing-masing kultivar dalam beradaptasi dengan konsentrasi larutan garam yang diberikan cukup baik. Hal tersebut sangat penting guna mendapatkan kultivar yang sesuai dalam usaha penggunaan larutan garam untuk mengatasi penyakit akar.

\section{Kesimpulan dan Saran}

Kesimpulan. Berdasarkan hasil percobaan yang telah dilakukan, maka dapat ditarik simpulan sebagai berikut:

1. Tidak terdapat hubungan yang saling mempengaruhi antara pengaruh lima kultivar asparagus dan berbagai konsentrasi larutan garam terhadap pertumbuhan, hasil rebung dan kualitas rebung.

2. Pertumbuhan dan kualitas rebung asparagus tidak berbeda pada lima kultivar asparagus yang di uji. Namun, persentase jumlah dan bobot rebung layak pasar pada kultivar Atlas dan Jaleo lebih tinggi dibanding pada kultivar De Paoli.

3. Perbedaan konsentrasi larutan garam tidak berpengaruh terhadap pertumbuhan, hasil panen dan kualitas rebung.

Saran. Hal yang dapat disarankan untuk percobaan selanjutnya adalah:

1. Percobaan ini perlu dilanjutkan pada periode panen selanjutnya.

2. Perlu dilanjutkan dengan menggunakan pengapuran untuk mencegah penurunan $\mathrm{pH}$ tanah akibat aplikasi larutan garam.

3. Perlu dilakukan percobaan serupa dengan penggunaan metode mother stalk pada periode panen rebung.

\section{Daftar Pustaka}

Ashari, S. 1995. Hortikultura: Aspek Budidaya. Jakarta: Universitas Indonesia Press. Hal 196.

Beltagi, M.S., M.A. Ismail and F.H. Mohamed. 2006. Induced salt tolerance in common bean (Phaseolus vulgaris L.) by gamma irradiation. J. Biology Science (6): 1143-1148.

Cantaluppi, C. J. 2012. Replicated Asparagus Cultivar Evaluation 2007-2012. Available at vegnet.osu.edu/sites/vegnet/files/imce/A 
sparagus \% 20trial.pdf (diakses pada 19 Desember 2016).

Drost, D. T. 1997. Asparagus. In The Physiology of Vegetable Crops. Wien, H.C. (Editor). CAB International. New York. p. 621-642.

Gaspersz, V. 2006. Teknik Analisis dalam Penelitian dan percobaan. Jilid 1. Bandung: Tarsito.

Gonzalez, M. 2008. Application of salt during seven years to an asparagus plantation affected by Fusarium. ISHS J. Acta Horticulturae 950: 32.

Grattan, S.R and C.M. Grieves. 1999. Salinitymineral nutrient relations in horticultural crops. J. Scientia Hort (78): 127-57.

Kruistum, G., J. T. Van, J. T. Poll, J. Meijer and M. Lievens. 2004. Effect of $\mathrm{NaCl}$ on asparagus quality, production and mineral leaching. Acta Horticulturae 776: 10.

Kusumiyati, T. M. Onggo dan F. A. Habibah. 2017. Pengaruh Konsentrasi Larutan Garam $\mathrm{NaCl}$ Terhadap Pertumbuhan dan Kualitas Bibit Lima Kultivar Asparagus. J. Hort. Vol. 27: 79-86.

Mathur, N., J. Singh, S. Bohra, A. Bohra and A. Vyas. 2006. Biomass production, productivity and physiological changes in moth bean genotypes at different salinity levels. J. Plant Physiol. (2) : 210-213.

Mazher, A. M. A., E. M. F. El-Quesni, M. M. Farahat. 2007. Responses of ornamental and woody trees to salinity. J. Agriculture
Science (3): 386-395.

Munns, R. 2002. Comparative physiology of salt and water stress. J. Plant Cell Environ 25: 239-250.

Onggo, T. M. 2008. Kualitas bibit dan potensi hasil sembilan kultivar introduksi asparagus di Lembang-Jawa Barat. Jurnal Agrikultura Vol. 19 (1) : 37-41.

. 2013. Budidaya Tanaman Asparagus Di Daerah Tropis. Bandung: Unpad Press. Hal 19-20.

Poll, J.T.K. and P.O. Bleeker. 1998. Effect of $\mathrm{NaCl}$ on weed populations in asparagus grown on a sandy soil. Netherlands: Applied Plant Research.

2002. Effect of $\mathrm{NaCl}$ on weed populations in asparagus grown on a sandy soil. Asparagus Research News Letter Vol.18 : 19-21.

Pranasari, R. A., N. Tutik dan K. I. Purwani. 2012. Persaingan tanaman jagung (Zea mays) dan rumput teki (Cyperus rotundus) pada pengaruh cekaman garam $(\mathrm{NaCl})$. J. Sains dan Seni ITS Vol. 1 (1) : 54-57.

Rubatzky, V. E. dan M. Yamaguchi. 1999. Sayuran Dunia Jilid ke-3. (Terjemahan). Bandung: Institut Teknologi Bandung Press. Hal 320.

Sudjatmiko, S. 1994. Keragaan Asparagus (Asparagus officinalis L.) pada suhu tropis ditinjau dari proses pertukaran carbondioksida. Prosiding Simposium : 185-189. 